\title{
Effects of Pueraria lobata Root Ethanol Extract on Adipogenesis and Lipogenesis During 3T3-L1 Differentiation into Adipocytes
}

\author{
Chae Myoung Lee ${ }^{1}$, Mi Sook Yoon' and Young Chul Kim² \\ 'Division of Beauty Cooperation, Keimyung College University, Daegu, Korea \\ ${ }^{2}$ Major in Public Health, Faculty of Food \& Health Sciences, Keimyung University, Daegu, Korea
}

(Received May 13, 2015; Revised June 10, 2015; Accepted June 14, 2015)

\begin{abstract}
We evaluated the inhibitory effect of Pueraria lobata root ethanol extract (PLREE) on lipid accumulation during 3T3-L1 differentiation to adipocytes by measuring the intracellular expression of adipogenic, lipogenic, and lipolytic markers and lipid accumulation. The total polyphenol and flavonoid content of PLREE were 47 and $29 \mathrm{mg} / \mathrm{g}$, respectively. The electron donating capacity of PLREE at 1,000 $\mu \mathrm{g} / \mathrm{mL}$ was $48.8 \%$. Treatment of 3T3-L1 preadipocytes with 100, 250, or $500 \mu \mathrm{g} / \mathrm{mL}$ PLREE for 8 days dose-dependently promoted the differentiation of 3T3-L1 cells. In contrast, the lipid content of PLREE-treated cells was significantly reduced by $7.8 \%(p<0.05), 35.6 \%(p<0.001)$, and $42.2 \%(p<0.001)$ following treatment with 100,250 , and $500 \mu \mathrm{g} / \mathrm{mL}$ PLREE, respectively, as compared to differentiated control cells. PLREE upregulated peroxisome proliferator-activated receptor $\gamma$ mRNA and protein, and sterol regulator element-binding protein-1c mRNA levels, but did not affect CCAAT/enhancer binding-protein $\beta$ and $\alpha$ mRNA levels. PLREE also downregulated acetyl-CoA carboxylase mRNA and protein, fatty acid synthase (FAS) protein, and leptin mRNA levels, but did not affect FAS mRNA expression. PLREE upregulated adipose triglyceride lipase mRNA and protein expression, and hormone-sensitive lipase (HSL) protein expression, but did not affect HSL mRNA expression. In conclusion, we found that PLREE enhanced adipogenesis, but reduced lipogenesis, resulting in decreased lipid accumulation in 3T3-L1 cells.
\end{abstract}

Key words: Adipogenesis, Lipid accumulation, Lipogenesis, 3T3-L1 preadipocytes, Pueraria lobata root ethanol extract

\section{INTRODUCTION}

UV radiation decreases the synthesis of free fatty acids (FFAs) and triglycerides (TGs) in the epidermis of human skin, contributing to the occurrence of skin photoaging (1). Sun exposure can also lead to subcutaneous (SC) fat loss through the inhibition of preadipocyte differentiation into mature adipocytes and stimulation of lipolysis in mature adipocytes (2). Thus, SC fat may have an important role in the maintenance of good health (3).

The transcriptional control of adipogenesis is largely influenced by the activation of several families of transcrip-

Correspondence to: Young Chul Kim, Major in Public Health, Faculty of Food \& Health Sciences, Keimyung University, 1095 Dalgubeol-daero, Daegu 704-701, Korea

E-mail: yckim@kmu.ac.kr

This is an Open-Access article distributed under the terms of the Creative Commons Attribution Non-Commercial License (http:// creativecommons.org/licenses/by-nc/3.0) which permits unrestricted non-commercial use, distribution, and reproduction in any medium, provided the original work is properly cited. tion factors. During adipogenesis, these transcription factors are coordinately expressed in a network in which CCAAT/enhancer-binding protein $\beta(\mathrm{C} / \mathrm{EBP} \beta)$ and $\mathrm{C} / \mathrm{EBP} \delta$ are detected first, followed by peroxisome proliferator-activated receptor $\gamma(\mathrm{PPAR} \gamma)$. PPAR $\gamma$ in turn activates $\mathrm{C} / \mathrm{EBP} \alpha$, which exerts positive feedback on PPAR $\gamma$ to maintain the differentiated state. Sterol regulatory element binding protein-1 (SREBP-1) can activate PPAR $\gamma$ by inducing its expression and promoting the production of endogenous PPAR $\gamma$ ligands. Combined, these factors contribute to the expression of genes that characterize terminally differentiated adipocytes (4). Thus, the differentiation process is controlled by these key adipogenic transcriptional factors (5).

Adipogenesis is a multi-faceted process that includes preadipocyte proliferation, differentiation, and intracellular lipid accumulation, as well as changes in the expression level of various genes in the adipogenic pathway (6). One of the most well established and frequently applied systems for studying adipocyte differentiation is the 3T3-L1 cell line, derived from mouse embryonic fibroblast preadipocytes (7). In previous studies, isoflavones, such as puerarin, 
daidzein, and genistein, from Kudzu root (Pueraria lobata), were shown to have both adipogenic (8-10) and anti-adipogenic activity $(7,11,12)$. Lipid accumulation reflects the process of differentiation, which is regulated by the increased expression of various transcription factors and adipogenesis-related genes (13). Thus, we analyzed the expression of these genes using semi-quantitative RT-PCR and western blotting to investigate the molecular mechanisms underlying $P$. lobata root ethanol extract (PLREE)-induced 3T3-L1 cell differentiation.

\section{MATERIALS AND METHODS}

Reagents and apparatus. Dimethyl sulfoxide (DMSO), 1,1-diphenyl-2-picryl hydrazyl (DPPH), tannic acid, ascorbic acid, Folin-Ciocalteu's phenol reagent, 3-(4,5-dimethylthiazol-2-yl)-2,5-diphenyl-tetrazolium bromide (MTT), 3isobutyl-1-methylxanthine (IBMX), insulin, dexamethasone, and Oil red $\mathrm{O}$ were purchased from Sigma-Aldrich (St. Louis, MO, USA). Dulbecco's modified Eagle's medium (DMEM), fetal bovine serum (FBS), and penicillin/streptomycin $(\mathrm{P} / \mathrm{S})$ were purchased from Lonza Company (Cascade, MD, USA). PPAR $\gamma$ (catalogue \#2435), acetyl-CoA carboxylase (ACC, catalogue \#3662), fatty acid synthase (FAS, catalogue \#3180), adipose triglyceride lipase (ATGL, catalogue \#2138), and hormone-sensitive lipase (HSL, catalogue \#4107) antibodies were purchased from Cell Signaling Technology (Danvers, MA, USA) and $\beta$-actin (catalogue sc-47778) antibody was purchased from Santa Cruz Biotechnology (Santa Cruz, CA, USA). Daidzein (>95\%) and genistein $(>95 \%)$ were purchased from Extrasynthese (Lyon, France), and puerarin ( $>95 \%$ ) was purchased from the Ministry of Food and Drug Safety (Cheongju, Korea). All reagents used in this study were of analytical grade. An inverted microscope (CKX41, Olympus, Tokyo, Japan) was used to observe cell growth. $\mathrm{A} \mathrm{CO}_{2}$ incubator (MCO17AC, SANYO Electric, Osaka, Japan) was used for cell culture.

Preparation of $P$. lobata root ethanol extract (PLREE). P. lobata root (Kim-Cheon product, Taechang Pharmaceutical Co., Ltd., Seoul, Korea) was purchased from Yakryeong market (Daegu, Korea). Pulverized samples (100 g) were put in a flask and extracted in $1,000 \mathrm{~mL} 80 \%$ ethanol 3 times for $24 \mathrm{hr}$ each at $25^{\circ} \mathrm{C}$. The extract was filtered with filter paper and concentrated using a rotary vacuum evaporator followed by lyophilization (yield 27.5\%).

Ultra-performance liquid chromatography (UPLC) measurements. Measurements were carried out on a Waters UPLC (Acquity UPLC ${ }^{\circledR}$, Waters, MA, USA) equipped with a Waters BEH C18 column $(1.7 \mu \mathrm{m}, 2.1 \mathrm{~mm} \times 100$ $\mathrm{mm}$ ) and a guard column at the Research Center for Biomedical Resources of Korean Medicine of Daegu Hanny
University (Daegu, Korea). Lyophilized PLREE (0.2 g) and $100 \%$ methanol $(10 \mathrm{~mL})$ were put in a Falcon tube and sonicated for $1 \mathrm{hr}$ using an ultrasonic cleaner (Power Sonic 405, Hwashin Technology Co., Daegu, Korea), followed by filtration with a membrane syringe filter (PTFE, $13 \mathrm{~mm}$, $0.2 \mu \mathrm{m}$, Dong-il Shimadzu Spechrom, Korea). The temperature was set at $35^{\circ} \mathrm{C}$, the injection volume was $2 \mu \mathrm{L}$, and the detection wave length of the photodiode array (PDA) detector was set to $254 \mathrm{~nm}$. Binary elution at a flow rate of $0.3 \mathrm{~mL} / \mathrm{min}$ was employed using an aqueous phase of $0.1 \%$ formic acid in deionized water as solvent $\mathrm{A}$ and $0.1 \%$ formic acid in acetonitrile as solvent $\mathrm{B}$, as follows: $10 \% \mathrm{~B}$ at $0 \sim 5 \mathrm{~min}, 10 \sim 30 \%$ at $5 \sim 8 \mathrm{~min}, 30 \sim 40 \%$ at $8 \sim 10$ $\mathrm{min}, 40 \sim 50 \%$ at $10 \sim 12 \mathrm{~min}, 50 \sim 10 \%$ at $12 \sim 14 \mathrm{~min}$, and $10 \%$ at $14 \sim 16 \mathrm{~min}$. The chromatograms were documented by Waters Empower 2 Chromatography Data Software (Waters).

Antioxidant activity. The Folin-Denis assay (14) was performed to determine the total polyphenol content of PLREE. PLREE $(1 \mathrm{~mL})$ and Folin reagent $(1 \mathrm{~mL})$ were placed in a test tube and allowed to stand for $3 \mathrm{~min}$, before adding $10 \% \mathrm{Na}_{2} \mathrm{CO}_{3}(1 \mathrm{~mL})$ and shaking vigorously. The tubes were incubated for $1 \mathrm{hr}$ at room temperature before measuring the absorbance at $725 \mathrm{~nm}$. A standard curve was prepared using tannic acid. The total flavonoid content of PLREE was determined by a modified Davies method (15). PLREE $(100 \mu \mathrm{L})$ was placed in a test tube before adding $1 \mathrm{~mL}$ diethylene glycol reagent and $100 \mu \mathrm{L} 1 \mathrm{~N} \mathrm{NaOH}$. The mixture was shaken vigorously and incubated at $37^{\circ} \mathrm{C}$ for $1 \mathrm{hr}$ before measuring the absorbance at $420 \mathrm{~nm}$. A standard curve was prepared using rutin. The electron donating ability was evaluated as previously described (16). PLREE $(1 \mathrm{~mL})$ dissolved in distilled water at concentrations of 250 , 500 , or $1,000 \mu \mathrm{g} / \mathrm{mL}$ was placed in a test tube before adding $0.4 \mathrm{mM}$ DPPH $(4 \mathrm{~mL})$. The mixture was shaken vigorously and incubated for $10 \mathrm{sec}$ at $60^{\circ} \mathrm{C}$ before measuring the absorbance at $525 \mathrm{~nm}$. Ascorbic acid was used as a positive control. The DPPH radical scavenging activity of each solution was calculated as the percent inhibition with the following equation:

$$
\% \text { donating ability }=\left[1-\left(\mathrm{A}_{\text {sample }} / \mathrm{A}_{\text {control }}\right)\right] \times 00
$$

where $\mathrm{A}_{\text {control }}$ is the absorbance of the control (reagents without test compounds).

Cell culture and sample treatment. 3T3-L1 preadipocytes, which were obtained from Professor Byeong Churl Jang (Keimyung University, Daegu, Korea), were cultured and differentiated as described by Fasshauer et al. (17). Briefly, the cells were cultured at $37^{\circ} \mathrm{C}$ in a humidified $5 \%$ $\mathrm{CO}_{2}$ atmosphere and grown in DMEM with $10 \%$ bovine calf serum (BCS) and 5\% $\mathrm{P} / \mathrm{S}$ (BCS/DMEM) medium. After inducing confluence for 2 days, preadipocytes were cultured in DMEM with $10 \% \mathrm{FBS}$ and $5 \% \mathrm{P} / \mathrm{S}$ (FBS/ 
DMEM) medium, supplemented with $0.5 \mathrm{mM}$ IBMX, $1 \mu \mathrm{M}$ DEX (MDI), and $10 \mu \mathrm{g} / \mathrm{mL}$ insulin for 2 days. The cell culture medium was replaced with DMEM containing $10 \mu \mathrm{g} /$ $\mathrm{mL}$ insulin, and incubation was continued for another 3 days. The cells were then maintained in DMEM with medium changes every 2 days. To examine the effect of PLREE on adipocyte differentiation, 3T3-L1 preadipocytes were cultured with MDI in the presence or absence of PLREE at the indicated concentrations. Differentiation, as measured by the expression of adipogenic markers and the appearance of lipid droplets, was completed on day 8 .

Cell viability assay. The effect of PLREE on 3T3-L1 preadipocyte viability was assessed by the MTT assay to determine the maximum permissible level (MPL). 3T3-L1 preadipocytes were seeded in a 96-well plate $\left(1.5 \times 10^{4}\right.$ cells/well) and incubated in a humidified $5 \% \mathrm{CO}_{2}$ atmosphere at $37^{\circ} \mathrm{C}$ for $24 \mathrm{hr}$. PLREE $(200 \mu \mathrm{L})$ diluted with DMEM to concentrations of $0 \sim 1,000 \mu \mathrm{g} / \mathrm{mL}$ was added to the wells, and the plate was incubated for an additional $48 \mathrm{hr}$. MTT $(0.5 \mu \mathrm{g} / \mathrm{mL})$ reagent was then added to each well, and the cells were further incubated for $3 \mathrm{hr}$. After centrifugation at $180 \times \mathrm{g}$ for $10 \mathrm{~min}$, the medium was removed, and $200 \mu \mathrm{L}$ DMSO was added for 15 min with shaking to resuspend the cells. Cell viability was assessed by absorbance at $540 \mathrm{~nm}$ using an ELISA reader (680, Bio-Rad, Tokyo, Japan).
Oil red 0 staining. On day 8, 3T3-L1 cells were washed twice with PBS and fixed with $10 \%(\mathrm{v} / \mathrm{v})$ fresh formalin for $2 \mathrm{hr}$. Cells were stained with Oil red $\mathrm{O}$ working solution for $1 \mathrm{hr}$. After the staining solution was removed, stained lipid droplets in 3T3-L1 cells were washed four times with distilled water. For the quantification of Oil red $\mathrm{O}$ uptake, cells were incubated with $1 \mathrm{~mL}$ isopropanol per well for $10 \mathrm{~min}$. After incubation, the soluble reactant was transferred to a 96-well plate, and absorbance was measured at $490 \mathrm{~nm}$ using a multi-well plate reader (Model 680, Biorad, Hercules, CA, USA).

Reverse transcription-polymerase chain reaction (RTPCR). Total RNA was extracted from 3T3-L1 cells treated with PLREE for 8 days using TRIzol reagent (Life Technologies, Carlsbad, CA, USA) according to the manufacturer's instructions. Equal amounts of total RNA $(5 \mu \mathrm{g})$ were reverse transcribed in a $40 \mu \mathrm{L}$ reaction mixture containing $8 \mu \mathrm{L}$ Molony murine leukemia virus reverse transcriptase (MMLV RT) $5 \times$ buffer, $10 \mathrm{mM}$ dNTPs $(3 \mu \mathrm{L}), 40 \mathrm{U} / \mu \mathrm{L}$ RNase inhibitor $(0.45 \mu \mathrm{L}), 200 \mathrm{U} / \mu \mathrm{L}$ M-MLV RT $(0.3 \mu \mathrm{L}$, Promega, Madison, WI, USA), and $20 \mu \mathrm{M}$ oligo dT $(3.75 \mu \mathrm{L}$, Bioneer, Daejeon, Korea). Single-stranded cDNA was then used as a template for PCR amplification reactions containing $4 \mu \mathrm{L}$ of $5 \times$ green Go Taq Flexi buffer, $10 \mathrm{mM}$ dNTPs $(0.4 \mu \mathrm{L})$, $5 \mathrm{U} / \mu \mathrm{L}$ Taq polymerase $(0.1 \mu \mathrm{L}), 25 \mathrm{mM} \mathrm{MgCl}_{2}(1.2 \mu \mathrm{L}$, Promega), and $0.4 \mu \mathrm{L}$ each primer $(20 \mu \mathrm{M})$. The primer

Table 1. Primer sequences for target genes used in 3T3-L1 cells for PCR

\begin{tabular}{|c|c|c|}
\hline Genes & Primers & 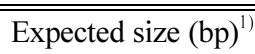 \\
\hline SREBP-1c & $\begin{array}{l}\text { Forward }\left(5^{\prime} \rightarrow 3^{\prime}\right) \text { GCG CTA CCG GTC TTC TAT CA } \\
\text { Reverse }\left(5^{\prime} \rightarrow 3^{\prime}\right) \text { TGC TGC CAA AAG ACA AGG G }\end{array}$ & 234 \\
\hline $\mathrm{C} / \mathrm{EBP} \beta$ & $\begin{array}{l}\text { Forward }\left(5^{\prime} \rightarrow 3^{\prime}\right) \text { GAC TAC GCA ACA CAC GTG TAA CT } \\
\text { Reverse }\left(5^{\prime} \rightarrow 3^{\prime}\right) \text { CAA AAC CAA AAA CAT CAA CAA CCC }\end{array}$ & 488 \\
\hline $\operatorname{PPAR} \gamma$ & $\begin{array}{l}\text { Forward }\left(5^{\prime} \rightarrow 3^{\prime}\right) \text { GGT GAA ACT CTG GGA GAT TC } \\
\text { Reverse }\left(5^{\prime} \rightarrow 3^{\prime}\right) \text { CAA CCA TTG GGT CAG CTC TC }\end{array}$ & 268 \\
\hline $\mathrm{C} / \mathrm{EBP} \alpha$ & $\begin{array}{l}\text { Forward }\left(5^{\prime} \rightarrow 3^{\prime}\right) \text { TTA CAA CAG GCC AGG TTT CC } \\
\text { Reverse }\left(5^{\prime} \rightarrow 3^{\prime}\right) \text { CTC TGG GAT GGA TCG ATT GT }\end{array}$ & 232 \\
\hline $\mathrm{ACC}$ & $\begin{array}{l}\text { Forward }\left(5^{\prime} \rightarrow 3^{\prime}\right) \text { TGA CCG TGG GCA CAA AGT T } \\
\text { Reverse }\left(5^{\prime} \rightarrow 3^{\prime}\right) \text { AGG AGG AAC CGC ATT TAT CGA }\end{array}$ & 351 \\
\hline FAS & $\begin{array}{l}\text { Forward }\left(5^{\prime} \rightarrow 3^{\prime}\right) \text { GGT TCG GAA TGC TAT CCA GG } \\
\text { Reverse }\left(5^{\prime} \rightarrow 3^{\prime}\right) \text { CTG CGG AAA CTT CAG GAA AT }\end{array}$ & 301 \\
\hline Leptin & $\begin{array}{l}\text { Forward }\left(5^{\prime} \rightarrow 3^{\prime}\right) \text { CCA AAA CCC TCA TCA AGA CC } \\
\text { Reverse }\left(5^{\prime} \rightarrow 3^{\prime}\right) \text { CTC AAA GCC ACC ACC TCT GT }\end{array}$ & 352 \\
\hline ATGL & $\begin{array}{l}\text { Forward }\left(5^{\prime} \rightarrow 3^{\prime}\right) \text { TTC ACC ATC CGC TTG TTG } \\
\text { Reverse }\left(5^{\prime} \rightarrow 3^{\prime}\right) \text { AGT TCC ACC TGC TCA GAC }\end{array}$ & 155 \\
\hline HSL & $\begin{array}{l}\text { Forward }\left(5^{\prime} \rightarrow 3^{\prime}\right) \text { GTC GCC TTT CTC CTG ATG AC } \\
\text { Reverse }\left(5^{\prime} \rightarrow 3^{\prime}\right) \text { CTT GCT GCT TCT CTT GGC TC }\end{array}$ & 410 \\
\hline GAPDH & $\begin{array}{l}\text { Forward }\left(5^{\prime} \rightarrow 3^{\prime}\right) \text { GTA TGA CTC CAC TCA CGG CAA A } \\
\text { Reverse }\left(5^{\prime} \rightarrow 3^{\prime}\right) \text { GGT CTC GCT CCT GGA AGA TG }\end{array}$ & 248 \\
\hline
\end{tabular}

${ }^{1)} \mathrm{bp}$ : basepair. 
Table 2. PCR conditions for target genes in 3T3-L1 cells

\begin{tabular}{|c|c|c|c|c|}
\hline Genes & Items & Temperature & Time & Cycles \\
\hline \multirow{5}{*}{ SREBP-1c } & Predenaturation & $95^{\circ} \mathrm{C}$ & $10 \mathrm{~min}$ & 1 \\
\hline & Denaturation & $95^{\circ} \mathrm{C}$ & $1 \mathrm{~min}$ & \multirow{3}{*}{30} \\
\hline & Annealing & $54^{\circ} \mathrm{C}$ & $1 \mathrm{~min}$ & \\
\hline & Extension & $72^{\circ} \mathrm{C}$ & $1 \mathrm{~min}$ & \\
\hline & Post extension & $72^{\circ} \mathrm{C}$ & $10 \mathrm{~min}$ & 1 \\
\hline \multirow{5}{*}{$\mathrm{C} / \mathrm{EBP} \beta$} & Predenaturation & $95^{\circ} \mathrm{C}$ & $10 \mathrm{~min}$ & 1 \\
\hline & Denaturation & $94^{\circ} \mathrm{C}$ & $30 \mathrm{sec}$ & \multirow{3}{*}{30} \\
\hline & Annealing & $53^{\circ} \mathrm{C}$ & $30 \mathrm{sec}$ & \\
\hline & Extension & $72^{\circ} \mathrm{C}$ & $30 \mathrm{sec}$ & \\
\hline & Post extension & $72^{\circ} \mathrm{C}$ & $7 \mathrm{~min}$ & 1 \\
\hline \multirow{5}{*}{$\operatorname{PPAR} \gamma$} & Predenaturation & $95^{\circ} \mathrm{C}$ & $10 \mathrm{~min}$ & 1 \\
\hline & Denaturation & $94^{\circ} \mathrm{C}$ & $30 \mathrm{sec}$ & \multirow{3}{*}{30} \\
\hline & Annealing & $53^{\circ} \mathrm{C}$ & $30 \mathrm{sec}$ & \\
\hline & Extension & $72^{\circ} \mathrm{C}$ & $30 \mathrm{sec}$ & \\
\hline & Post extension & $72^{\circ} \mathrm{C}$ & $7 \mathrm{~min}$ & 1 \\
\hline \multirow{5}{*}{$\mathrm{C} / \mathrm{EBP} \alpha$} & Predenaturation & $94^{\circ} \mathrm{C}$ & $10 \mathrm{~min}$ & 1 \\
\hline & Denaturation & $94^{\circ} \mathrm{C}$ & $30 \mathrm{sec}$ & \multirow{3}{*}{30} \\
\hline & Annealing & $62^{\circ} \mathrm{C}$ & $30 \mathrm{sec}$ & \\
\hline & Extension & $72^{\circ} \mathrm{C}$ & $30 \mathrm{sec}$ & \\
\hline & Post extension & $72^{\circ} \mathrm{C}$ & $7 \mathrm{~min}$ & 1 \\
\hline \multirow{5}{*}{$\begin{array}{l}\text { ACC } \\
\text { FAS }\end{array}$} & Predenaturation & $94^{\circ} \mathrm{C}$ & $5 \mathrm{~min}$ & 1 \\
\hline & Denaturation & $94^{\circ} \mathrm{C}$ & $30 \mathrm{sec}$ & \multirow{3}{*}{30} \\
\hline & Annealing & $56^{\circ} \mathrm{C}$ & $1 \min$ & \\
\hline & Extension & $72^{\circ} \mathrm{C}$ & $1 \mathrm{~min}$ & \\
\hline & Post extension & $72^{\circ} \mathrm{C}$ & $5 \mathrm{~min}$ & 1 \\
\hline \multirow{5}{*}{ Leptin } & Predenaturation & $94^{\circ} \mathrm{C}$ & $1 \mathrm{~min}$ & 1 \\
\hline & Denaturation & $94^{\circ} \mathrm{C}$ & $1 \mathrm{~min}$ & \multirow{3}{*}{33} \\
\hline & Annealing & $57^{\circ} \mathrm{C}$ & $1 \mathrm{~min}$ & \\
\hline & Extension & $72^{\circ} \mathrm{C}$ & $2 \min$ & \\
\hline & Post extension & $72^{\circ} \mathrm{C}$ & $7 \mathrm{~min}$ & 1 \\
\hline \multirow{5}{*}{$\begin{array}{l}\text { ATGL } \\
\text { HSL }\end{array}$} & Predenaturation & $94^{\circ} \mathrm{C}$ & $5 \mathrm{~min}$ & 1 \\
\hline & Denaturation & $94^{\circ} \mathrm{C}$ & $45 \mathrm{sec}$ & \multirow{3}{*}{29} \\
\hline & Annealing & $53^{\circ} \mathrm{C}$ & $45 \mathrm{sec}$ & \\
\hline & Extension & $72^{\circ} \mathrm{C}$ & $90 \mathrm{sec}$ & \\
\hline & Post extension & $72^{\circ} \mathrm{C}$ & $5 \min$ & 1 \\
\hline
\end{tabular}

sequences and PCR conditions are shown in Tables 1 and 2, respectively. PCR products were visualized after ethidium bromide staining on a $1.2 \%$ agarose gel. The DNA band density was semi-quantitatively analyzed using the KODAK Gel Logic 100 image analysis system (Eastman Kodak Co., Rochester, NY, USA). The relative mRNA expression level of target genes was calculated by normalization with that of GAPDH as an internal control.

Western blot analysis. 3T3-L1 cells treated with PLREE for 8 days in $60-\mathrm{mm}$ cell culture dishes were washed with cold PBS, harvested using a cell scraper, lysed with lysis buffer containing $1 \times$ RIPA (Sigma-Aldrich), $2 \mathrm{mM}$ phenylmethylsulfonyl fluoride (PMSF), $1 \mathrm{mM} \mathrm{Na} \mathrm{VO}_{4}, 1 \mathrm{mM}$ $\mathrm{NaF}, 1 \mathrm{mM}$ glycerol 2-phosphate disodium salt hydrate $(\mathrm{G})$, and $1 \times$ protease inhibitor $(\mathrm{PI})$, followed by incubation on ice for $10 \mathrm{~min}$. Cell lysates were centrifuged at $18,000 \times \mathrm{g}$ for $20 \mathrm{~min}$ at $4^{\circ} \mathrm{C}$, and protein content in the resultant supernatants was measured using the BSA Protein Assay Reagent Kit (Biorad). Equal amounts of protein $(30 \mu \mathrm{g})$ were separated by electrophoresis in a $10 \%$ polyacrylamide gel, transferred onto nitrocellulose membrane, and incubated with specific antibodies against PPAR $\gamma(1: 1,000)$, ACC $(1: 1,000)$, FAS $(1: 1,000)$, ATGL $(1: 1,000)$, or HSL $(1: 1,000)$. The membrane was then incubated with anti-rabbit $\operatorname{IgG}(1: 1,000)$. Immunoreactive bands were detected using ECL western blotting detection reagents (Biorad). Band intensity was semi-quantified using the Image J program (NIH, Bethesda, $\mathrm{MD}, \mathrm{USA})$ and $\beta$-actin was used as an internal control.

Statistical analysis. Data are presented as the mean \pm SD. Significance was analyzed by Student's $t$-test, using SPSS 21.0 for Windows (IBM, Armonk, NY, USA). Differences between experimental groups were considered to be significant when $p<0.05$.

\section{RESULTS}

Daidzein, genistein and puerarin content of PLREE. PLREE contained $1.77 \mathrm{mg} / \mathrm{g}$ daidzein, $0.26 \mathrm{mg} / \mathrm{g}$ genistein, and $148.44 \mathrm{mg} / \mathrm{g}$ puerarin (Fig. 1).

Antioxidant activity of PLREE. The total polyphenol content of PLREE was $47 \mathrm{mg} / \mathrm{g}$, as determined using the tannic acid standard curve (Fig. 2). The total flavonoid content of PLREE was $29 \mathrm{mg} / \mathrm{g}$, as determined by the rutin standard curve (Fig. 2). The electron donating ability of ascorbic acid and PLREE at $1,000 \mu \mathrm{g} / \mathrm{mL}$ was $90.2 \%$ and $48.8 \%$, respectively (Fig. 3 ). The electron donating ability of PLREE was relatively lower than ascorbic acid.

Effect of PLREE on 3T3-L1 preadipocyte viability. To examine PLREE-induced cytotoxicity, 3T3-L1 preadipocyte viability after exposure to $100 \sim 1,000 \mu \mathrm{g} / \mathrm{mL}$ PLREE for $48 \mathrm{hr}$ was evaluated by MTT assay. Cells were still viable at all PLREE concentrations tested, as compared to vehicle-treated cells (Fig. 4). The maximum permissible level (MPL) of PLREE was over 1,000 $\mu \mathrm{g} / \mathrm{mL}$. Morphological observation of 3T3-L1 cells treated with 200 1,000 $\mu \mathrm{g} /$ $\mathrm{mL}$ PLREE using an inverted microscope did not show any morphological changes, as compared to vehicle-treated cells (figures not shown).

Effect of PLREE on lipid accumulation. To determine the potential effect of PLREE on adipogenesis, 3T3-L1 

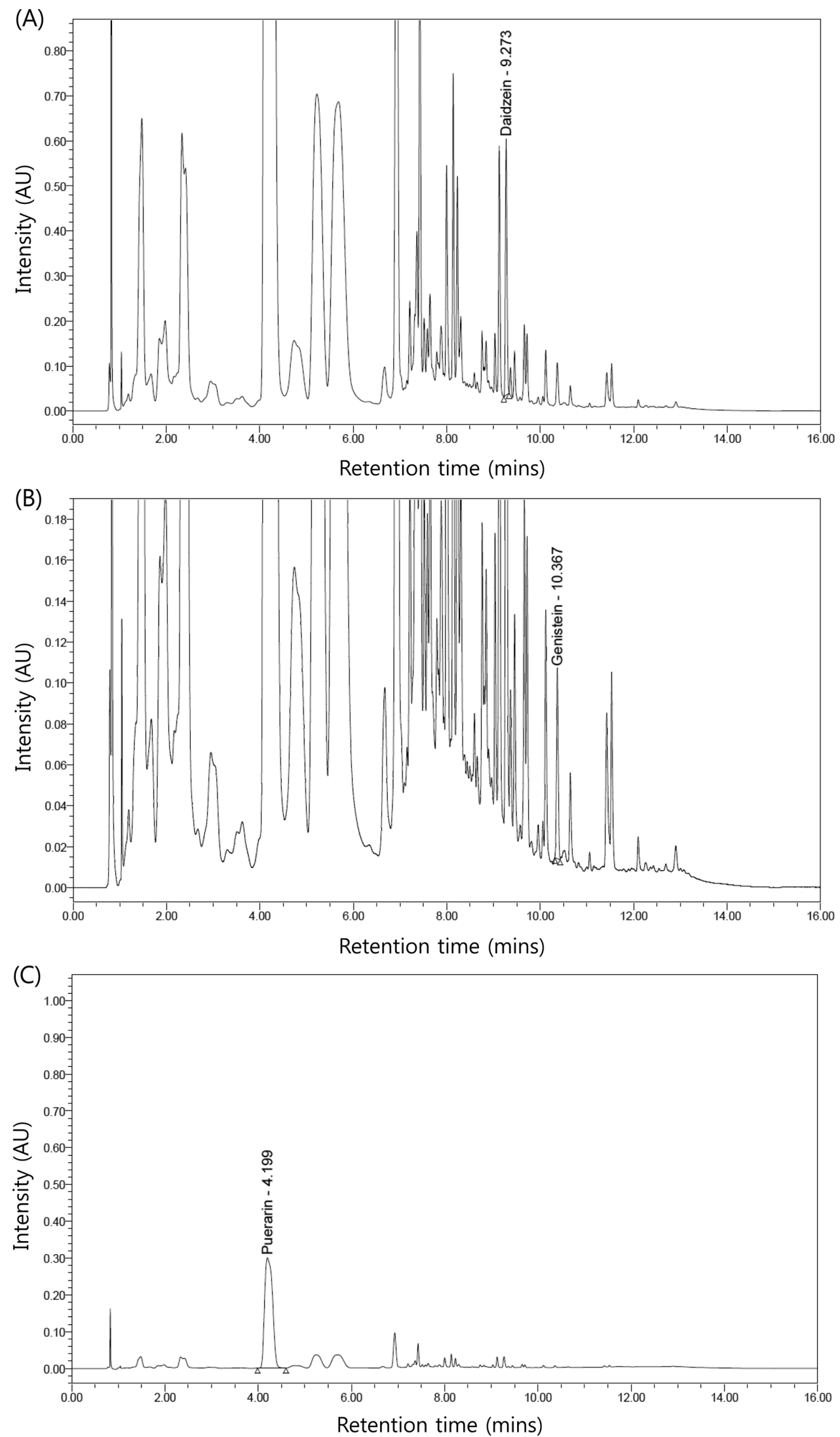

Fig. 1. UPLC chromatograms of Pueraria lobata root ethanol extract (PLREE). (A) daidzein, (B) genistein, (C) puerarin. 


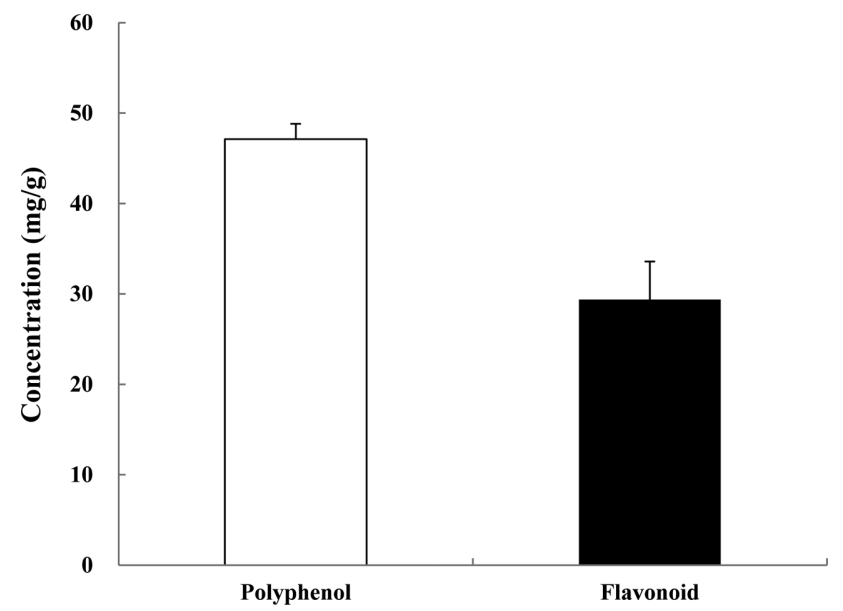

Fig. 2. Total polyphenol and flavonoid content of PLREE. Values represent the mean $\pm S D$ of three independent measurements.

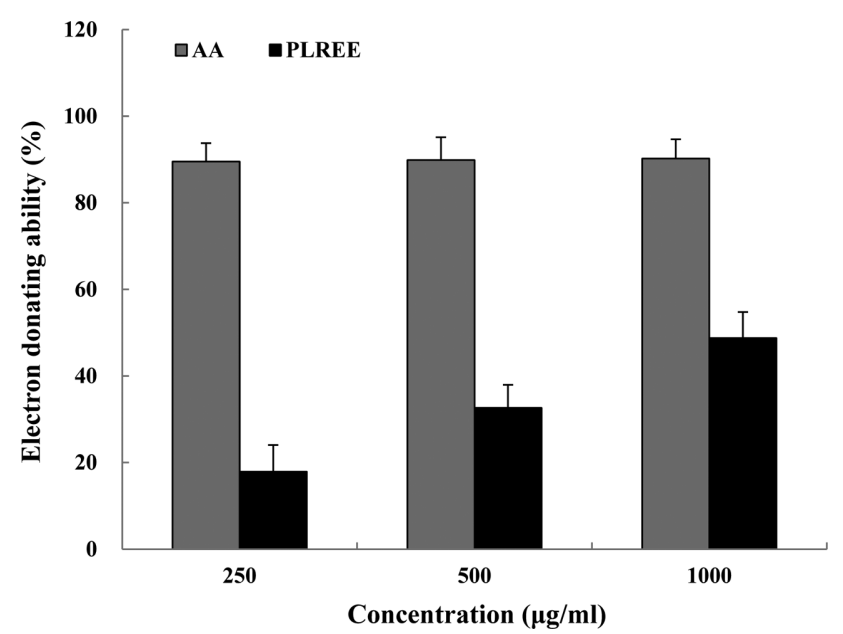

Fig. 3. Electron donating ability of PLREE and ascorbic acid. Each substance was evaluated on its ability to provide electrons to the free radical DPPH. Values represent the mean \pm SD of three independent measurements. AA: ascorbic acid.

preadipocytes were grown to confluence, and differentiation was induced, with or without standard MDI hormonal inducers, in the absence or presence of PLREE (100, 250, or $500 \mu \mathrm{g} / \mathrm{mL}$ ). On day 8 , the degree of adipocyte differentiation was evaluated by microscopic observation (Fig. 5). Undifferentiated cells had spindle-like shapes and few lipid droplets, whereas differentiated control cells had a round shape and many lipid droplets. The PLREE-treated cells had fewer lipid droplets, as compared to differentiated control cells.

On day 8 , the degree of lipid accumulation was assessed by Oil red $\mathrm{O}$ staining and imaging (Fig. 6). Undifferentiated cells displayed little lipid accumulation, whereas differentiated control cells were observed with many lipid

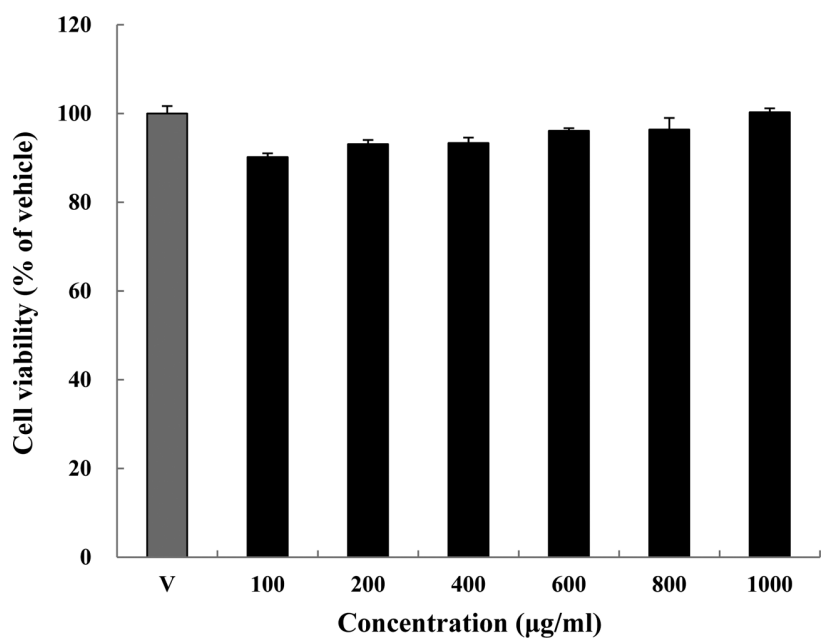

Fig. 4. Effect of PLREE on viability of 3T3-L1 preadipocytes. Viability of 3T3-L1 preadipocytes treated with PLREE (100 1,000 $\mu \mathrm{g} / \mathrm{mL}$ ) for $48 \mathrm{hr}$ was analyzed by MTT assay. Values represent the mean \pm SD of three independent measurements. V: vehicle.

droplets. However, PLREE-treatment dose-dependently reduced lipid droplets, as compared to differentiated control cells. Quantitative analysis revealed that the lipid content of PLREE-treated cells was significantly and dosedependently reduced at 100,250 , and $500 \mu \mathrm{g} / \mathrm{mL}$ by $7.8 \%$ $(p<0.05), 35.6 \%(p<0.001)$, and $42.2 \%(p<0.001)$, respectively (Fig. 7).

Effect of PLREE on MRNA expression of adipogenic, lipogenic, and lipolytic genes. Among adipogenic genes, PLREE remarkably upregulated SREBP-1c and PPAR $\gamma$ mRNA expression as compared to control cells, but did not affect $\mathrm{C} / \mathrm{EBP} \beta$ and $\mathrm{C} / \mathrm{EBP} \alpha$ at transcriptional levels. Among lipogenic genes, PLREE downregulated ACC and leptin mRNA expression, but had no effect on FAS mRNA expression. Among lipolytic genes, PLREE upregulated ATGL mRNA expression, but did not affect HSL mRNA expression (Fig. 8).

Effect of PLREE on PPAR $\gamma$, ACC, FAS, ATGL, and HSL protein expression. Compared to control cells, PLREE upregulated PPAR $\gamma$, ATGL, and HSL protein expression, whereas PLREE downregulated ACC and FAS protein expression (Fig. 9).

\section{DISCUSSION}

In the current study, PLREE upregulated the mRNA and protein expression of a key adipogenic transcription factor, PPAR $\gamma$, during the differentiation of 3T3-L1 preadipocytes to adipocytes. In contrast, SREBP-1c, another adipogenic transcription factor, was only weakly upregulated by PLREE. Interestingly, $\mathrm{C} / \mathrm{EBP} \alpha \mathrm{mRNA}$ expression was not affected 

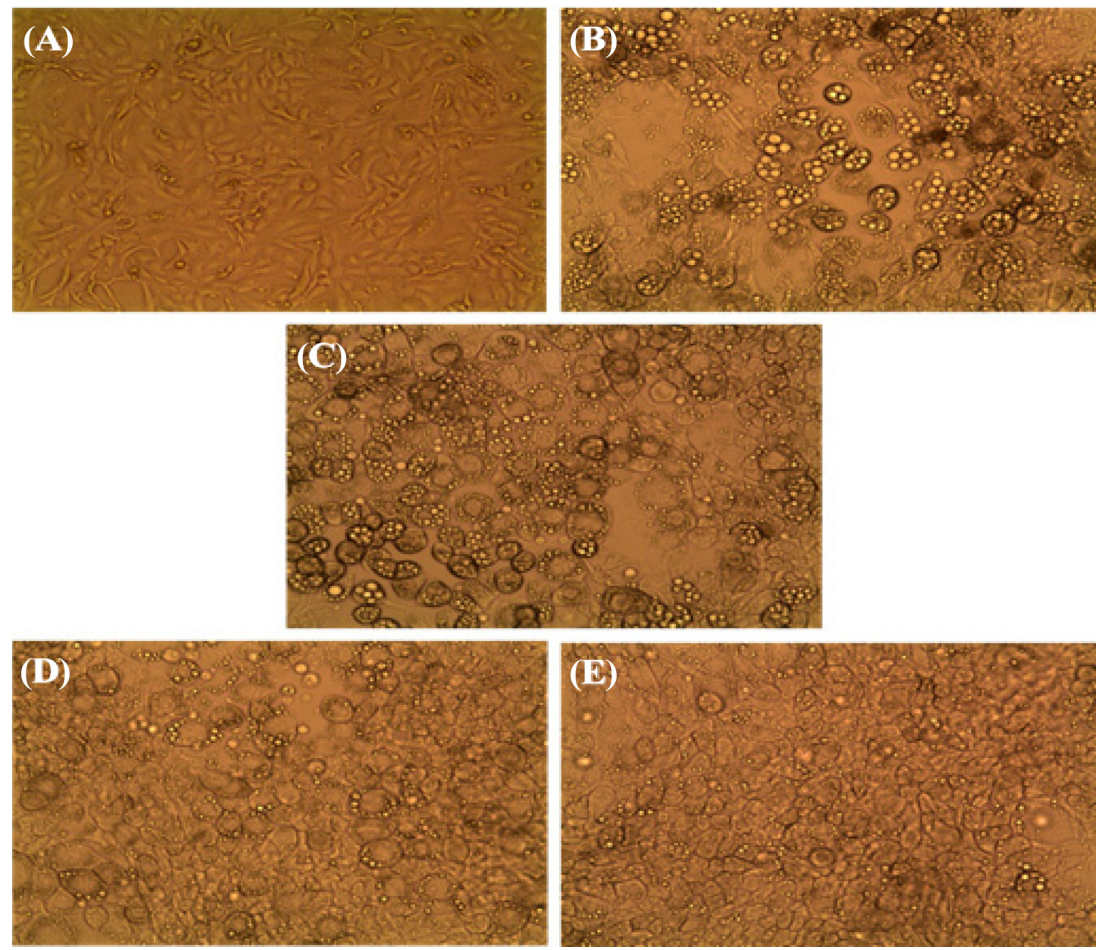

Fig. 5. Effect of PLREE on the differentiation of 3T3-L1 preadipocytes into adipocytes. 3T3-L1 preadipocytes were induced to differentiate in the presence of PLREE at $100 \mu \mathrm{g} / \mathrm{mL}(C), 250 \mu \mathrm{g} / \mathrm{mL}$ (D), and $500 \mu \mathrm{g} / \mathrm{mL}$ (E) for 8 days, and then microscopic images of the conditioned cells on day 8 were compared to undifferentiated normal cells (A) and differentiated control cells (B). 200× magnification.

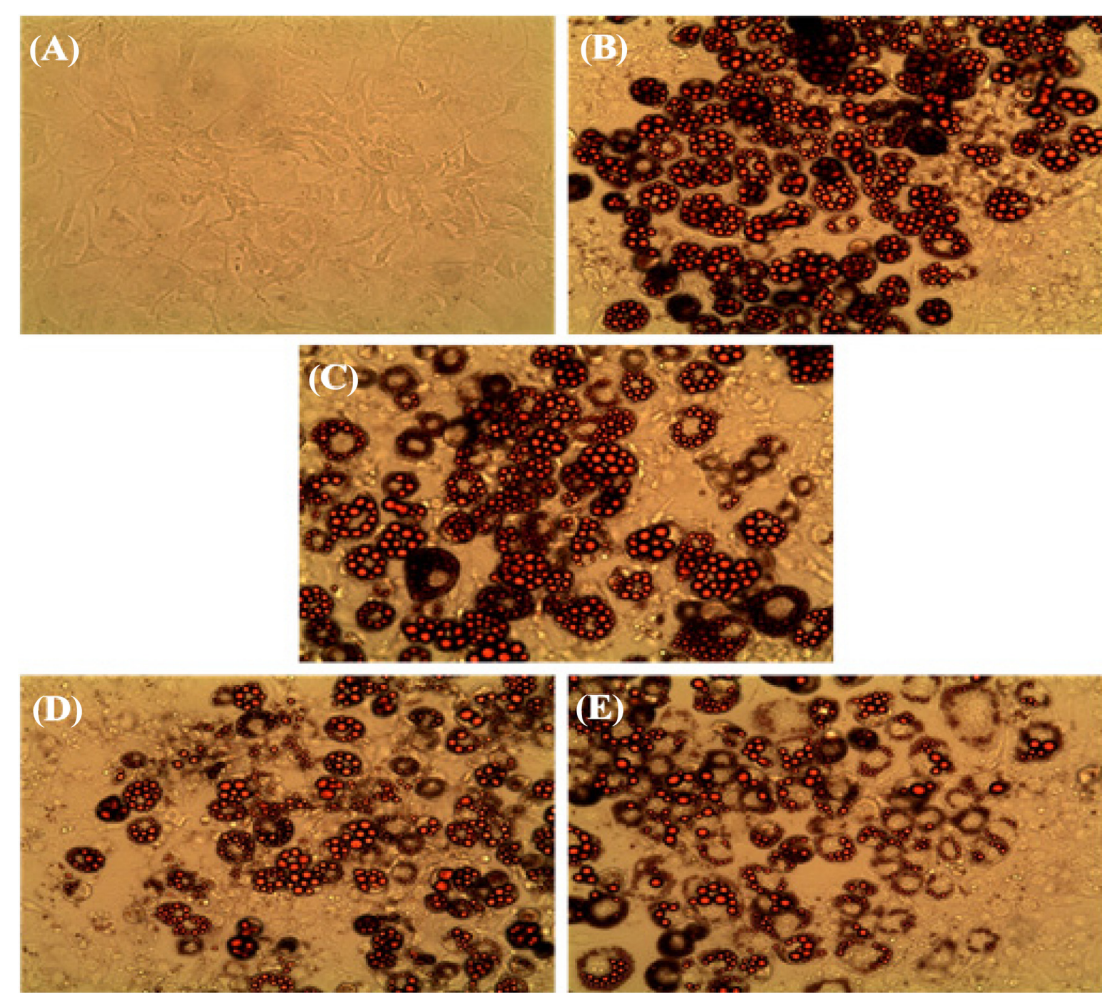

Fig. 6. Effect of PLREE on lipid accumulation during the differentiation of 3T3-L1 preadipocytes into adipocytes. 3T3-L1 preadipocytes were treated with PLREE at $100 \mu \mathrm{g} / \mathrm{mL}$ (C), $250 \mu \mathrm{g} / \mathrm{mL}$ (D), and $500 \mu \mathrm{g} / \mathrm{mL}$ (E) for 8 days, and microscopic images of Oil red Ostained 3T3-L1 cells (day 8) were compared to undifferentiated normal cells (A) and differentiated control cells (B). 200× magnification. 


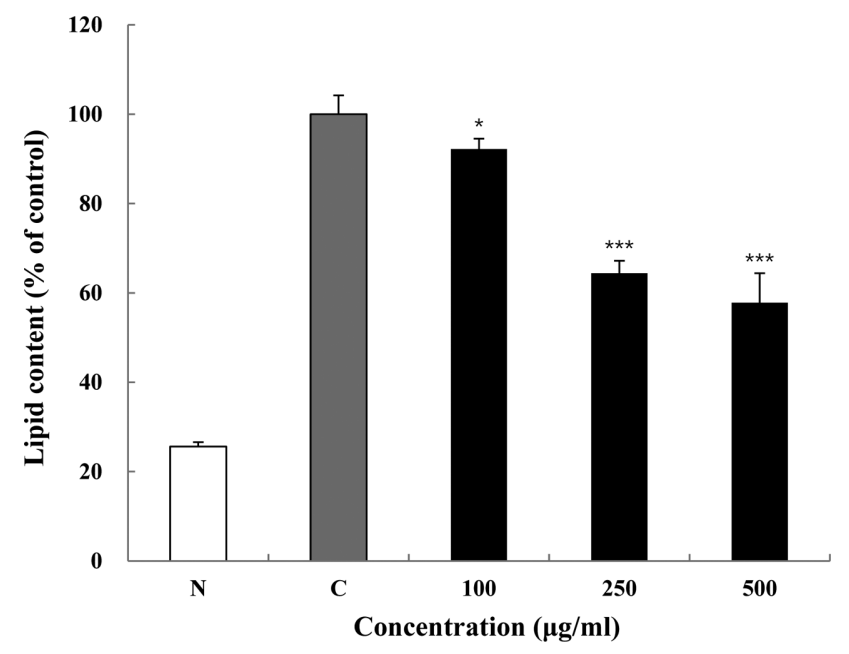

Fig. 7. Effect of PLREE on lipid conversion during the differentiation of 3T3-L1 preadipocytes into adipocytes. 3T3-L1 preadipocytes were treated with PLREE for 8 days, and lipid content was quantified by extracting Oil red $\mathrm{O}$ dye in the cells by isopropanol and measuring OD at $490 \mathrm{~nm}$. Values represent the mean \pm SD of three independent measurements. ${ }^{*} p<0.05,{ }^{* * *} p<0.001$ compared to differentiated control cells. $\mathrm{N}$ : undifferentiated normal cells, C: differentiated control cells. by PLREE. In addition, no changes in C/EBP $\beta$ mRNA expression levels were observed in response to PLREE. Because $\mathrm{C} / \mathrm{EBP} \beta$ is an early adipogenic marker, this finding may be explained by the use of fully differentiated cells for mRNA expression analysis (18).

Adipogenic transcription factors coordinately regulate the expression of adipocyte-specific genes, including fatty acid synthase (FAS) and acetyl-CoA carboxylase (ACC) (5). ACC, a rate-limiting enzyme for fatty acid synthesis, catalyzes the first reaction step in fatty acid synthesis, promoting synthesis of long-chain fatty acids and reducing fatty acid oxidation (19). Moreover, inhibition of ACC has been shown to prevent the differentiation of 3T3-L1 cells (20). FAS catalyzes the synthesis of saturated fatty acids, predominately palmitate, from acetyl-CoA and malonyl-CoA precursors. This enzyme is highly expressed in the liver, adipose tissue, and lactating mammary glands (21). Malonyl-CoA generated by ACC1 is utilized by FAS for the synthesis of fatty acids in the cytosol, and ACC, FAS, and stearoyl-CoA desaturase 1 (SCD 1) play important roles in the development of hepatic steatosis and insulin resistance (22). In the current study, PLREE downregulated ACC mRNA and protein expression during the differentiation of 3T3-L1
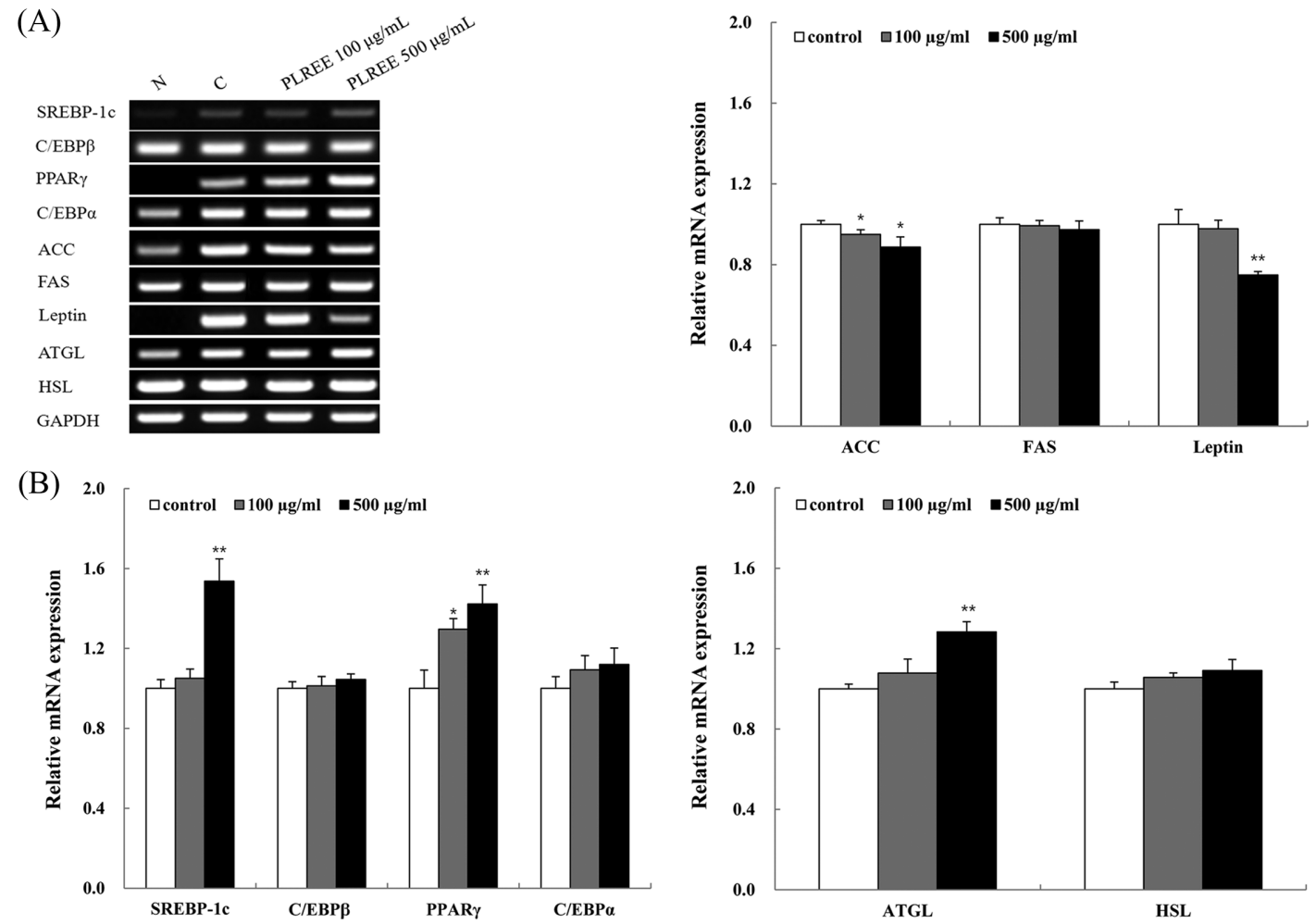

Fig. 8. Effect of PLREE on mRNA expression of adipogenic, lipogenic, and lipolytic genes during the differentiation of 3T3-L1 preadipocytes into adipocytes. (A) 3T3-L1 preadipocytes were treated with PLREE for 8 days, and mRNA levels of adipogenic, lipogenic, and lipolytic genes in 3T3-L1 cells (day 8) were analyzed by semi-quantitative RT-PCR. Expression was normalized to GAPDH levels. (B) Quantification of mRNA levels of adipogenic, lipogenic, and lipolytic genes. Values represent the mean \pm SD of three independent measurements. ${ }^{*} p<0.05,{ }^{* *} p<0.01$ compared to differentiated control cells. $\mathrm{N}$ : undifferentiated normal cells, C: differentiated control cells. 
(A)
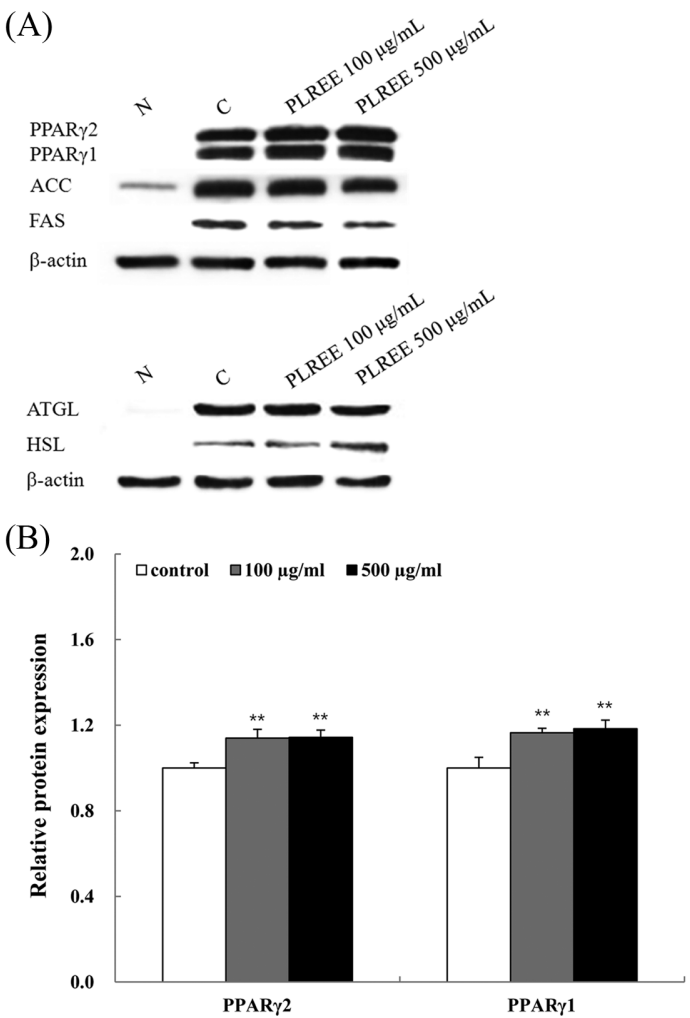
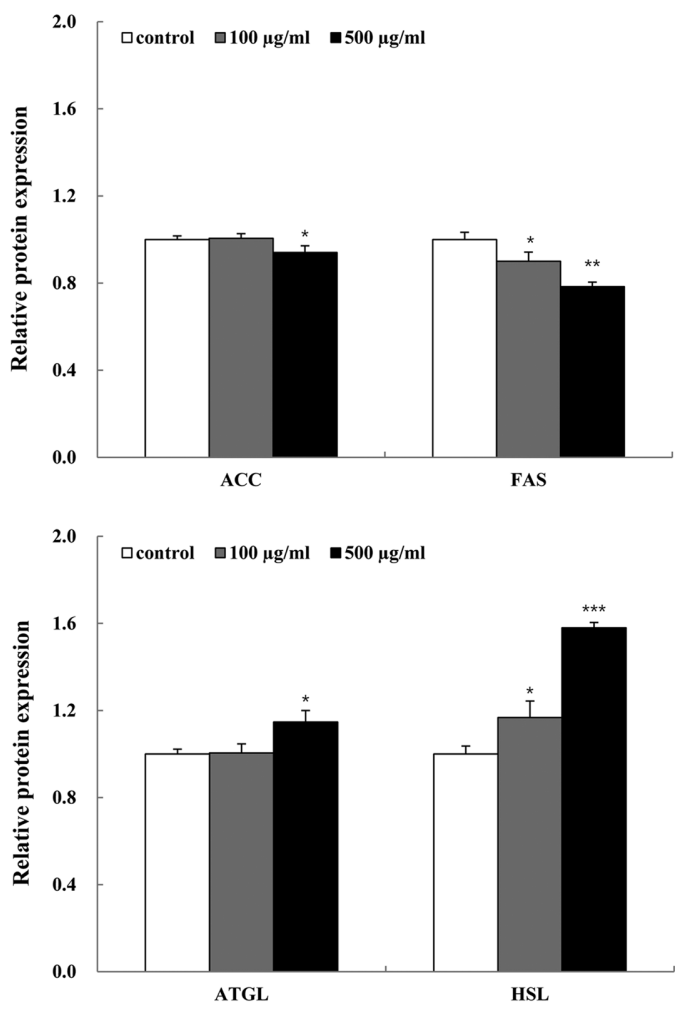

Fig. 9. Effect of PLREE on PPAR, ACC, FAS, ATGL, and HSL protein expression during the differentiation of 3T3-L1 preadipocytes into adipocytes. (A) 3T3-L1 preadipocytes were treated with PLREE for 8 days, and protein levels of PPAR $\gamma$, ACC, FAS, ATGL, and HSL in 3T3L1 cells (day 8) were measured by western blotting. Expression was normalized to $\beta$-actin levels. (B) Quantification of protein levels of PPAR $\gamma$, ACC, FAS, ATGL, and HSL genes. Values represent the mean \pm SD of three independent measurements. ${ }^{*} p<0.05,{ }^{* *} p<0.01$, ${ }^{* * *} p<0.001$ compared to differentiated control cells. $\mathrm{N}$ : undifferentiated normal cells, C: differentiated control cells.

cells. PLREE also downregulated FAS protein expression, but did not affect FAS mRNA expression. Thus, these results confirmed that PLREE enhanced adipogenesis but reduced lipogenesis in 3T3-L1 cells.

Lipolysis is the chemical decomposition and release of fat from adipose tissue. Lipolysis predominates over lipogenesis when additional energy is required (23). HSL and ATGL are two important rate-limiting enzymes for fat decomposition reactions $(24,25)$. ATGL, the main lipase involved in the initial step of TG hydrolysis, functions to generate diglyceride (DG) and FFAs, after which HSL hydrolyzes DG (26). Recent studies have shown that ATGL and HSL act sequentially to catalyze the first two steps of adipose lipolysis in response to $\beta$-adrenergic stimulation (27). Moreover, lipolysis can be enhanced by increasing ATGL and HSL expression (28). In the current study, PLREE weakly upregulated ATGL mRNA and protein expression during the differentiation of 3T3-L1 preadipocytes into adipocytes. PLREE, however, did not affect HSL mRNA expression. Rather, it upregulated HSL protein expression. These finding may be explained by the observation that ATGL precedes HSL in adipose lipolysis (18). The final step of the lipolytic process is efflux of fatty acids and glycerol from adipocytes
(29).

Relic et al. (8) reported that, as compared with cultures treated with genistein and rosiglitazone alone, the numbers of Oil red O-stained droplets in combined cultures are markedly increased, suggesting that genistein and rosiglitazone act synergistically on synovial adipogenesis through the PPAR $\gamma$ pathway. In this study, we examined the effects of PLREE on lipid accumulation using Oil red $\mathrm{O}$ staining and lipid quantification. From these analyses, we found that PLREE markedly reduced lipid accumulation during the differentiation of 3T3-L1 cells. Therefore, our results suggest that downregulation of ACC and/or FAS, and upregulation of ATGL and/or HSL ultimately resulted in the suppression of lipid accumulation in 3T3-L1 cells. Taxvig et al. (7) reported that genistein inhibits lipid accumulation in 3T3-L1 cells. However, they also found that a mixture of isoflavonoid parent compounds or a mixture of isoflavonoid metabolites could activate PPAR $\gamma$. Because the activation of PPAR $\gamma$ is generally related to stimulation of adipocyte differentiation, they suggested that the inhibitory effect of genistein on lipid accumulation in 3T3-L1 cells is only partly dependent on PPAR $\gamma$, and that other mechanisms may be involved. One possibility is that the effect of genistein could 
be mediated through the estrogen receptor (7). In the current study, we also found that PLREE reduced lipid accumulation during the differentiation of 3T3-L1 cells, but upregulated PPAR $\gamma$. In previous studies, puerarin has been reported to enhance the differentiation of 3T3-L1 preadipocytes (10). Interestingly, genistein and daidzein have been reported to have both adipogenic and anti-adipogenic activities $(7-9,11,12)$. In the current study, PLREE contained high amount of puerarin and some daidzein and zenistein.

In conclusion, the present study demonstrated that PLREE enhanced adipogenesis, but reduced lipogenesis, resulting in decreased lipid accumulation in 3T3-L1 cells. The potential adipogenic and anti-lipogenic activities of PLREE might be isoflavones including puerarin, daidzein, and genistein; however, which components act on stimulation of adipocyte differentiation and inhibition of lipid accumulation during the differentiation of 3T3-L1 preadipocytes into adipocytes need to be further investigated deeply.

\section{REFERENCES}

1. Kim, E.J., Jin, X.J., Kim, Y.K., Oh, I.K., Kim, J.E., Park, C.H. and Chung, J.H. (2010) UV decreases the synthesis of free fatty acids and triglycerides in the epidermis of human skin in vivo, contributing to development of skin photoaging. J. Dermatol. Sci., 57, 19-26.

2. Li, W.H., Pappas, A., Zhang, L., Ruvolo, E. and Cavender, D. (2013) IL-11, IL-1 $\alpha$, IL-6, and TNF- $\alpha$ are induced by solar radiation in vitro and may be involved in facial subcutaneous fat loss in vivo. J. Dermatol. Sci., 71, 58-66.

3. Kim, E.J., Kim, Y.K., Kim, J.E., Kim, S., Kim, M.K., Park, C.H. and Chung, J.H. (2011) UV modulation of subcutaneous fat metabolism. J. Invest. Dermatol., 131, 1720-1726.

4. Rosen, E.D., Walkey, C.J., Puigserver, P. and Spiegelman, B.M. (2000) Transcriptional regulation of adipogenesis. Genes Dev., 14, 1293-1307.

5. Kim, M.B., Song, Y., Kim, C. and Hwang, J.K. (2014) Kirenol inhibits adipogenesis through activation of the Wnt/ $\beta$-catenin signaling pathway in 3T3-L1 adipocytes. Biochem. Biophys. Res. Commun., 445, 433-438.

6. Lee, H., Bae, S. and Yoon, Y. (2013) The anti-adipogenic effects of (-) epigallocatechin gallate are dependent on the WNT/ $\beta$-catenin pathway. J. Nutr. Biochem., 24, 1232-1240.

7. Taxvig, C., Specht, I.O., Boberg, J., Vinggaard, A.M. and Nellemann, C. (2013) Dietary relevant mixtures of phytoestrogens inhibit adipocyte differentiation in vitro. Food Chem. Toxicol., 55, 265-271.

8. Relic, B., Zeddou, M., Desoroux, A., Beguin, Y., de Seny, D. and Malaise, M.G. (2009) Genistein induces adipogenesis but inhibits leptin induction in human synovial fibroblasts. $L a b$. Invest., 89, 811-822.

9. Cho, K.W., Lee, O.H., Banz, W.J., Moustaid-Moussa, N., Shay, N.F. and Kim, Y.C. (2010) Daidzein and the daidzein metabolite, equol, enhance adipocyte differentiation and PPAR gamma transcriptional activity. J. Nutr. Biochem., 21, 841847.

10. Lee, O.H., Seo, D.H., Park, C.S. and Kim, Y.C. (2010) Puer- arin enhances adipocyte differentiation, adiponectin expression, and antioxidant response in 3T3-L1 cells. Biofactors, 36, 459-467.

11. Harmon, A.W., Patel, Y.M. and Harp, J.B. (2002) Genistein inhibits CCAAT/enhancer-binding protein beta (C/EBP beta) activity and 3T3-L1 adipogenesis by increasing C/EBP homologous protein expression. Biochem. J., 367, 203-208.

12. Park, H.J., Della-Fera, M.A., Hausman, D.B., Rayalam, S., Ambati, S. and Baile, C.A. (2009) Genistein inhibits differentiation of primary human adipocytes. J. Nutr. Biochem., 20, 140-148.

13. Rosen, E.D. and Spiegelman, B.M. (2006) Adipocytes as regulators of energy balance and glucose homeostasis. Nature, 444, 847-853.

14. Folin, O. and Denis, W. (1912) On phosphotungstic-phosphomolybdic compounds as color reagents. J. Biol. Chem., 12, 239-243.

15. Davies, R., Massey, R.C. and McWeeny, D.J. (1980) The catalysis of the $N$-nitrosation of secondary amines by nitrosophenols. Food Chem., 6, 115-122.

16. Blois, M.S. (1958) Antioxidant determinations by the use of a stable free radical. Nature, 181, 1199-1200.

17. Fasshauer, M., Klein, J., Neumann, S., Eszlinger, M. and Paschke, R. (2001) Isoproterenol inhibits resistin gene expression through a $\mathrm{G}(\mathrm{S})$-protein-coupled pathway in 3T3-L1 adipocytes. FEBS Lett., 500, 60-63.

18. Rayalam, S., Della-Fera, M.A., Yang, J.Y., Park, H.J., Ambati, S. and Baile, C.A. (2007) Resveratrol potentiates genistein's antiadipogenic and proapoptotic effects in 3T3-L1 adipocytes. J. Nutr., 137, 2668-2673.

19. Barber, M.C., Price, N.T. and Travers, M.T. (2005) Structure and regulation of acetyl-CoA carboxylase genes of metazoa. Biochim. Biophys. Acta, 1733, 1-28.

20. Levert, K.L., Waldrop, G.L. and Stephens, J.M. (2002) A biotin analog inhibits acetyl-CoA carboxylase activity and adipogenesis. J. Biol. Chem., 277, 16347-16350.

21. Schmida, B., Rippmann, J.F., Tadayyon, M. and Hamilton, B.S. (2005) Inhibition of fatty acid synthase prevents preadipocyte differentiation. Biochem. Biophys. Res. Commun., 328, 1073-1082.

22. Wakil, S.J. and Abu-Elheiga, L.A. (2009) Fatty acid metabolism: target for metabolic syndrome. J. Lipid Res., 50, 138143.

23. Li, Y.C., Zheng, X.L., Liu, B.T. and Yang, G.S. (2010) Regulation of ATGL expression mediated by leptin in vitro in porcine adipocyte lipolysis. Mol. Cell. Biochem., 333, 121-128.

24. Zimmermann, R., Strauss, J.G., Haemmerle, G., Schoiswohl, G., Birner-Gruenberger, R., Riederer, M., Lass, A., Neuberger, G., Eisenhaber, F., Hermetter, A. and Zechner, R. (2004) Fat mobilization in adipose tissue is promoted by adipose triglyceride lipase. Science, 306, 1383-1386.

25. Shen, W.J., Patel, S., Miyoshi, H., Greenberg, A.S. and Kraemer, F.B. (2009) Functional interaction of hormone sensitive lipase and perilipin in lipolysis. J. Lipid Res., 50, 2306-2313.

26. Villena, J.A., Roy, S., Sarkadi-Nagy, E., Kim, K.H. and Sul, H.S. (2004) Desnutrin, an adipocyte gene encoding a novel patatin domain-containing protein, is induced by fasting and glucocorticoids: ectopic expression of desnutrin increases triglyceride hydrolysis. J. Biol. Chem., 279, 47066-47075. 
27. Yang, X., Zhang, X., Heckmann, B.L., Lu, X. and Liu, J. (2011) Relative contribution of adipose triglyceride lipase and hormone-sensitive lipase to tumor necrosis factor- $\alpha$ (TNF- $\alpha$ )induced lipolysis in adipocytes. J. Biol. Chem., 286, 4047740485.

28. Li, L., Yang, Y., Yang, G., Lu, C., Yang, M., Liu, H. and Zong,
H. (2011) The role of JAZF1 on lipid metabolism and related genes in vitro. Metabolism, 60, 523-530.

29. Kowalska, K., Olejnik, A., Rychlik, J. and Grajek, W. (2014) Cranberries (Oxycoccus quadripetalus) inhibit adipogenesis and lipogenesis in 3T3-L1 cells. Food Chem., 148, 246-252. 